\title{
Improvement of Technology of Bioenergetic Raw Material by Cavitational Homogenization of River Blue-Green Water Plants
}

\author{
Myroslav Malovanyy ${ }^{1}$, Ivan Aftanaziv ${ }^{2}$, Liliya Shevchuk ${ }^{3}$, Iryna Koval ${ }^{4}$, Orysia Strogan ${ }^{2}$ \\ 1. Department of Ecology and Balanced Natural Resources Viacheslav of Chornovil Institute of Sustainable \\ Development, Lviv Polytechnic National University, UKRAINE, Lviv, S. Bandery 12, 79013 \\ 2. Department of Descriptive Geometry and Engineering Graphics, Lviv Polytechnic National University, \\ UKRAINE, Lviv, S. Bandery 12, 79013, E-mail: ivan.aftanaziv@gmain.com
}

3. Department of Organic Products Technology, Lviv Polytechnic National University, UKRAINE, Lviv, S. Bandery 12,79013

4. Department of Physical, Analytical and General Chemistry, Lviv Polytechnic National University, UKRAINE, Lviv, S. Bandery 12, 79013, E-mail: irynazk@gmail.com

\begin{abstract}
The improved technological scheme of fermentational processing blue-greenwater plants into biogas includes three main blocks is proposed. The block of accumulating and preparation of water suspension of blue-green water plants, the block of preparation of the biomass of blue-green water plants by homogenization with vibro activators and the block of biogas fermentation by the process of "methane fermentation" includes. As a result the output of the ready product, biogas from 1 ton ofblue-green water plants bio-mass is about $30 \mathrm{~m}^{3}$, which equals 0.6 tons of oil or 0.51 tons of diesel fuel.
\end{abstract}

Keywords - blue-green water plants, vibroresonance cavitation, technological scheme, homogenization.

\section{Introduction}

One of the most active pollutants of fresh water on the territory of Ukraine is diverse species of the so-called Cyanobacteria, named blue-green water plants. On our territory there are about ten species, the most widely- spread, according to Parker System of Water Plants, belong to Procaryota kingdom, to Cianophycota class, to Cianophyceae family. During its vegetation period (70-120 days) one initial cell of cyanobacterium can produce $10^{20}$ ones, this fact accounts for their massive development, known as "flowering of water" [1]. The volume of water infected by cyanobacteria and, consequently, the number of cyanobacteria in waters of Ukraine is enormous. According to this research, carried out only on Kremenchuk reservoir with the area of water mirror 2250 square kilometers and volume of 828 billion cubic meters of shallow water at average thickness of water saturation by cyanobacteria $50 \mathrm{kilo} / \mathrm{m}^{3}$, then general biomass equals $4.14 * 10^{7}$ tons of accumulations during the whole summer vegetation period [2]. Water polluted by cyanobacteria not only deteriorates ecology of reservoirs and environment, but also becomes unfit and dangerous for people and animals, because of possible poisoning as a result of using it.

\section{Description}

The aim of the research is improvement of technology of blue-green water plants processing into bio-gas by their cavitational homogenization.

Cavitational processing of water suspension of blue-green water plants due to appearing cavitational microbulbs of striking micro waves while splashing, in turn changing zones of high and low pressure, as well as intensive influence of self created in cavitational field chemically active oxidizers radicals $\mathrm{OH}^{-}$and hydrogen peroxide $\mathrm{H}_{2} \mathrm{O}_{2}$ on membranes and covers of water plants, actively ruins covers of water plants and frees their cell contents. This way is defended by a patent for a useful model of Ukraine and provides using hydrodynamic cavitation on the stage 
of "extraction and bio-decomposition" [2]. It accelerates the speed of ruining covers of cyanobacteria by $20-25 \%$.

To accelerate the effectiveness of blue-greenwater plants cavitational homogenization an improved construction of a vibroresonance vibroactivator is proposed [3]. The essence of the improvement is that agitators of cavitation are installed opposite each other on the fluctuating and fixed on the frames of starters; the outer surface of them has the shape of hyperboloid of rotation, and the side surface has the shape of drawn into the hyperboloid hemisphere with a radius equal to double scope of working camera oscillation.

Based on experimental research data of vibroresonance cavitational processing of bluegreen water plants suspension taking plant suspension taking into consideration constructive opportunities and characteristic features of the elaborated construction of an industrial vibroactivator, an improved principal technological scheme of the process of processing of bluegreen water plants into biogas is proposed. This scheme includes three main blocks, namely: I block is a block of accumulating raw material and preparation of water suspension of bluegreenwater plants; II block is a block of vibroresonanse homogenization of water plant suspension; and III block is a block of bio-gas fermentation by anaerobic methane fermentation.

The difference of the proposed technological process of processing blue-green plants into biogas from typically traditional is supplementary installation of cavitational installation of cavitational homogenization of biomass in this block. As a result the output of the product, biogas, is about $30 \mathrm{~m}^{3}$ from 1 ton for biomass of blue-green plants which equals in thermal capacity of burning 0.6 tons of oil or 0.51 tons of diesel fuel.

\section{Conclusion}

1. The results of this research are applicable to two important aspects of mankind. Firstly, it is improvement of environmental ecology due to annihilation of active pollutants of natural water, cyanobacteria. Secondly, a very important sphere of energetics, bioenergetics, is improved; it is based on using renewable sources of energy, blue-green water plants.

2. Homogenization of blue-green suspension with equipment of vibroresonance cavitation raised volumes of fermentation by $25-30 \%$ from their biomass of biogas. This is $10-15 \%$ higher level comparing to homogenization of water plant biomass by hydrodynamic cavitational processing with paddle cavitators, and exceeds volumes of fermentation after ultrasound processing by $15-20 \%$.

\section{References}

[1] M. M. Malovanyy etc., "Optymal'ni umovy otrymannya enerhiyi iz tsianobakteriy," Khimichna promyslovist' Ukrayiny, no. 5, pp. 39-43, 2014.

[2] M. M. Malovanyy etc., " Reduction of the environmental threat from uncontrolled development of cyanobacteria in waters of Dnipro reservoirs," Environmental Problems, no. 1, pp. 61-64, 2016.

[3] V. L. Starchevskyy etc., “ Vibratsiynyy elektromahnitnyy kavitator,” Patent u 201400823 , no. 107769, 10 July, 2014. 